\title{
Effect of DPP-4 inhibitor on elderly patients with T2DM combined with MCI
}

\author{
JUJUN XUE ${ }^{1 *}$, CUIQING WANG $^{2 *}$, CHENGLI PAN $^{1}$, HAINING XING $^{3}$, \\ LIJUAN XU ${ }^{4}, \mathrm{XI} \mathrm{CHEN}^{5}, \mathrm{XUPING} \mathrm{WANG}^{4}$ and $\mathrm{NA} \mathrm{WANG}^{6}$ \\ Departments of ${ }^{1}$ Gerontological Neurology, ${ }^{2}$ Pediatric Clinic, ${ }^{3}$ Mass Control Office, ${ }^{4}$ Endocrinology, \\ ${ }^{5}$ Experimental Diagnosis and ${ }^{6}$ Medical Affairs, Heilongjiang Provincial Hospital, Harbin, Heilongjiang 150001, P.R. China
}

Received September 12, 2019; Accepted November 8, 2019

DOI: $10.3892 /$ etm.2019.8339

\begin{abstract}
The aim of this study was to investigate the effect of dipeptidyl peptidase-4 (DPP-4) inhibitor on blood sugar level and cognitive ability in elderly patients with type 2 diabetes mellitus (T2DM) combined with post-stroke mild cognitive impairment (MCI). Thirty patients received DPP-4 inhibitor (study group), while another thirty received sulfonylurea (control group).Six months after treatment, markers regarding blood sugar were improved in both groups (all $\mathrm{P}<0.05)$ without intergroup differences (all $\mathrm{P}>0.05$ ); scores regarding cognitive ability improved in the study group (both $\mathrm{P}<0.05$ ) and were higher versus the control group (both $\mathrm{P}<0.01$ ); the study group had higher $A \beta 1-42 / A \beta 1-40$ value versus the pretreatment value $(\mathrm{P}<0.001)$, which differed from the control group $(\mathrm{P}<0.05)$; tumor necrosis factor- $\alpha$ and interleukin- 6 concentrations decreased in both groups, while the study group had greater reductions; C-reactive protein value decreased after treatment in the study group (all $\mathrm{P}<0.05$ ).Using DPP-4 inhibitor in elderly patients with T2DM combined with post-stroke
\end{abstract}

Correspondence to: Dr Xuping Wang, Department of Endocrinology, Heilongjiang Provincial Hospital, 82 Zhongshan Road, Xiangfang, Harbin, Heilongjiang 150001, P.R. China

E-mail: wangxuping082@163.com

Dr Na Wang, Department of Medical Affairs, Heilongjiang Provincial Hospital, 82 Zhongshan Road, Xiangfang, Harbin, Heilongjiang 150001, P.R. China

E-mail: wangna79jx@163.com

${ }^{*}$ Contributed equally

Abbreviations: DPP-4, dipeptidyl peptidase-4; T2DM, type 2 diabetes mellitus; MCI, mild cognitive impairment; CI, cognitive impairment; GLP-1, glucagon-like peptide-1; AD, Alzheimer's disease; MCI, mild cognitive impairment; MMSE, Mini-Mental State Examination; FBG, fasting blood glucose; 2hPG, 2-hour postprandial blood glucose; HbAlc, hemoglobin Alc; CRP, C-reactive protein; TNF, tumor necrosis factor; IL, interleukin; MoCA, Montreal Cognitive Assessment

Key words: cognitive impairment, blood sugar, efficacy
MCI can lower blood sugar and improve cognitive ability. The mechanism may be associated with the improvement of $A \beta$ gathering and reduction in inflammatory response.

\section{Introduction}

Incidence of type 2 diabetes mellitus (T2DM) has been rising each year due to trends in population aging. It has been estimated that by 2040, there will be 615 million people suffering from T2DM (1). Meanwhile, morbidity of cognitive impairment (CI) increases as patients age. Some studies have documented that the incidence rate of CI is $5-10 \%$ in patients over 65 years old and $20-50 \%$ in patients over 85 years, with a higher prevalence in women than in men (2). Stroke is believed to be the second biggest factor in inducing CI (3). There have been studies revealing that T2DM is one of the common risk factors in causing stoke and CI. Thus patients with T2DM are more likely to have cognitive dysfunction after a stroke (4-6).

Regarding the pathogenesis, it has been reported that T2DM and CI share common lesion characteristics including $\mathrm{A} \beta$ gathering, decreased ability in regulating protein phosphorylation, and participation of chronic inflammatory factors; moreover, insulin resistance and damage to insulin signal transmission are also common pathological bases in the occurrence of both diseases $(7,8)$. Glucagon-like peptide-1 (GLP-1) is an endogenous incretin. It can promote the release of insulin from islet cell and keep the glucose content at a relatively stable level in the body (9). Some recent studies have demonstrated that GLP-1 can not only affect pancreatic islet function but also display neurotransmitter-like and neuron growth factor-like properties (10). GLP-1 agents, such as liraglutide and exenatide, have been demonstrated to be able to mitigate neurodegeneration in Alzheimer's disease (AD) and decrease memory and learning disabilities when used in the rat model of $\mathrm{AD}(11,12)$. However, some studies have found that GLP-1 gets readily hydrolyzed by dipeptidyl peptidase-4 (DPP-4) in the body, causing loss of activity and function. DPP-4 inhibitors including sitagliptin, vildagliptin, and linagliptin reduce sugar level mainly through inhibiting GLP-1 hydrolysis (13). Currently, studies regarding the improvement of cognitive ability by DPP-4 were primarily carried out among patients with $\mathrm{AD}$, whereas studies performed in patients with T2DM combined with post-stroke mild cognitive impairment 
(MCI) were few $(14,15)$. Therefore, in the present study, we used DPP-4 inhibitor in treating elderly patients with T2DM combined with post-stroke MCI and investigated its effect on patients' blood sugar level and cognitive ability.

\section{Materials and methods}

Patient characteristics. The present study was approved by the Ethics Committee of Heilongjiang Provincial Hospital, (Harbin, China) and informed consent was obtained from all individuals included in this study. Sixty patients treated in the department of neurology in Heilongjiang Provincial Hospital between January 2017 and June 2018 for T2DM combined with post-stroke CI were selected and randomized into a study group (treated with DPP-4 inhibitor) and a control group (treated with sulfonylurea) of 30 patients each. All patients were aged above 65 years.

Inclusion criteria were as follows: i) Patients who met the diagnostic criteria for T2DM (16); ii) patients who met the diagnostic criteria for post-stroke CI after assessment of cognitive ability and the condition was stabilized after treatment (17); iii) patients who met the following four criteria for MCI: a) patients with a score of $\geq 24$ points in Mini-Mental State Examination (MMSE, 19 items, total score of 30 points); b) patients with a score of $<26$ points in Montreal Cognitive Assessment (MoCA) if they had over 12 years of education (one point was added to the MoCA score if patients did not have over 12 years of education); c) patients were reported by themselves or their family members to have hypomnesia; d) activity of daily living score $<26$ points (18); iv) patients had diabetes before stroke occurrence, and the antidiabetic drugs patients received were sulfonylurea and metformin instead of DPP-4 inhibitor.

Exclusion criteria were: i) Patients who were allergic to DPP inhibitor; ii) patients who had histories of craniocerebral trauma, epilepsy, and cerebrovascular disease; iii) patients who would not cooperate with cognitive testing; iv) patients who were taking glucocorticoid which would affect blood sugar level; v) patients who had cardiopulmonary insufficiency; vi) patients who had malignant tumors; vii) patients who had mental illness which would affect cognition.

Methods. According to a random number table, patients in the study were assigned to either a study group or a control group of 30 patients each. In the study group, patients received oral administration of $100 \mathrm{mg}$ sitagliptin (Merck Sharp \& Dohme, Ltd., registration number for imported medicine: H20090834), a DPP-4 inhibitor, one time per day and one pill each time; meanwhile, patients in the control group received sulfonylurea. If the blood sugar level was not lowered effectively, regular insulin would be administered temporarily to control the sugar content. Efficacy was evaluated at six months after treatment.

Outcome measures. Main outcome measures were: i) fasting blood glucose (FBG), 2-hour postprandial blood glucose (2hPG), and hemoglobin A1c (HbA1c) values before and six months after treatment; FBG and $2 \mathrm{hPG}$ were measured using Accu-Chek Performa blood glucose meter (Roche), while HbA1c was measured using DCA 2000 analyzer (Bayer); ii) MMSE and MoCA scores before and six months after treatment for cognitive evaluation.
Secondary outcome measures included C-reactive protein (CRP), tumor necrosis factor (TNF)- $\alpha$, interleukin (IL)-6, and $\mathrm{A} \beta 1-40$ and $\mathrm{A} \beta 1-42$ values. Two tubes of venous blood $(5 \mathrm{ml}$ each) were collected from each patient at 8 'clock in the morning before and six months after treatment. The blood samples were placed in sterile EDTA tubes and kept in a fridge at $4{ }^{\circ} \mathrm{C}$ for $15 \mathrm{~min}$. Afterward, samples were centrifuged at $1,500 \mathrm{x} \mathrm{g}$ at $4^{\circ} \mathrm{C}$ for $30 \mathrm{~min}$ to separate serum from plasma. The plasma was incubated with phosphate buffered saline containing $40 \mu \mathrm{l}$ protease inhibitor at $-80^{\circ} \mathrm{C}$. Levels of CRP, TNF- $\alpha$, and IL-6 in serum were measured using immunoturbidimetry, while values of $A \beta 1-40$ and $A \beta 1-42$ in plasma were measured using ELISA.

Statistical analysis. SPSS 17.0 software was applied for statistical analysis. Continuous variables are expressed as mean \pm SD. t-test was performed if there were normal distribution and homogeneity of variance; comparison between two groups was conducted by independent-samples t-test; before versus after comparison within the group was performed by paired t-test; quartile was presented, and Wilcoxon rank-sum test was conducted if there were no normal distribution and homogeneity of variance. Pearson's Chi-squared test was performed for count data. $\mathrm{P}<0.05$ was considered to indicate a statistically significant difference.

\section{Results}

Patient characteristics. There were no intergroup differences in sex, age, education background, body mass index, and comorbidities so that the results were comparable (all $\mathrm{P}>0.05$, Table I).

Sugar blood content before and after treatment in the two groups. No intergroup differences were found in FBG, 2hPG, and $\mathrm{HbA} 1 \mathrm{c}$ in the two groups before and after treatment (all $\mathrm{P}>0.05$ ). Compared with the pretreatment values, these markers improved significantly six months after treatment (all $\mathrm{P}<0.05$ ) (Table II).

Cognitive ability before and after treatment in the two groups. No intergroup differences were found in MMSE and MoCA scores in the two groups before treatment (both $\mathrm{P}>0.05$ ). However, at six months after treatment, the MMSE and MoCA scores in the study group improved significantly compared with the pretreatment scores (both $\mathrm{P}<0.05$ ). In the control group, the MMSE score was lower than that before the treatment $(\mathrm{P}<0.05)$. Differences were observed between the two groups regarding these scores after treatment (both $\mathrm{P}<0.01$ ). (Table III and Fig. 1).

A $\beta 1-42, A \beta 1-40$, and A $\beta 1-42 / A \beta 1-40$ levels in plasma before and after treatment in the two groups. There were no intergroup differences in $A \beta 1-42, A \beta 1-40$, and $A \beta 1-42 / A \beta 1-40$ levels before treatment (all $\mathrm{P}>0.05$ ). However, at six months after treatment, the value of $A \beta 1-42 / A \beta 1-40$ improved significantly in the study group $(\mathrm{P}<0.001)$, whereas the levels of the other two markers were similar to those before treatment (both $\mathrm{P}>0.05$ ). $\mathrm{A} \beta 1-42 / \mathrm{A} \beta 1-40$ value differed between the two groups after treatment $(\mathrm{P}<0.05)$ (Table IV and Fig. 2). 
Table I. Patient characteristics and baseline data.

\begin{tabular}{|c|c|c|c|c|}
\hline Characteristics & Study group $(n=30)$ & Control group $(n=30)$ & $\chi^{2} / \mathrm{t}$ value & P-value \\
\hline Sex (male:female) & $17: 13$ & $14: 16$ & 0.601 & 0.438 \\
\hline Age (years) & $68.5 \pm 7.1$ & $67.4 \pm 5.9$ & 0.692 & 0.492 \\
\hline Education (year) & $12.5 \pm 3.8$ & $11.9 \pm 4.0$ & 0.627 & 0.533 \\
\hline Body mass index $\left(\mathrm{kg} / \mathrm{m}^{2}\right)$ & $25.71 \pm 3.76$ & $25.59 \pm 4.28$ & 0.110 & 0.913 \\
\hline Diabetes duration & $8.17 \pm 3.05$ & $8.97 \pm 2.65$ & 0.534 & 0.128 \\
\hline Stroke type & & & 0.268 & 0.605 \\
\hline Ischemic stroke & 15 & 17 & & \\
\hline Hemorrhagic stroke & 15 & 13 & & \\
\hline \multicolumn{5}{|l|}{ Comorbidity } \\
\hline Hyperlipemia & & & 0.067 & 0.759 \\
\hline Yes & 17 & 16 & & \\
\hline No & 13 & 14 & & \\
\hline Hypertension & & & 0.635 & 0.426 \\
\hline Yes & 20 & 17 & & \\
\hline No & 10 & 13 & & \\
\hline Coronary heart disease & & & 0.287 & 0.592 \\
\hline Yes & 10 & 12 & & \\
\hline No & 20 & 18 & & \\
\hline Obesity & & & 0.635 & 0.426 \\
\hline Yes & 10 & 13 & & \\
\hline No & 20 & 17 & & \\
\hline Hyperhomocysteinemia & & & 0.373 & 0.542 \\
\hline Yes & 22 & 24 & & \\
\hline No & 8 & 6 & & \\
\hline Hyperuricemia & & & 0.693 & 0.405 \\
\hline Yes & 19 & 22 & & \\
\hline No & 11 & 8 & & \\
\hline
\end{tabular}

Table II. Sugar blood content before and after treatment in the two groups.

\begin{tabular}{|c|c|c|c|c|c|c|c|c|}
\hline $\begin{array}{l}\text { Sugar blood } \\
\text { content }\end{array}$ & $\begin{array}{l}\text { Study group } \\
\text { Before } \\
\text { treatment }\end{array}$ & $\begin{array}{c}\text { Control group } \\
\text { Before } \\
\text { treatment }\end{array}$ & t value & P-value & $\begin{array}{l}\text { Study group } \\
\text { After } \\
\text { treatment }\end{array}$ & $\begin{array}{c}\text { Control group } \\
\text { After } \\
\text { treatment }\end{array}$ & t value & P-value \\
\hline $\mathrm{FBG}(\mathrm{mmol} / \mathrm{l})$ & $9.51 \pm 1.24$ & $9.29 \pm 1.32$ & 0.666 & 0.508 & $7.19 \pm 1.81^{\mathrm{a}}$ & $7.17 \pm 1.77^{\mathrm{a}}$ & 0.050 & 0.960 \\
\hline $2 \mathrm{hPG}(\mathrm{mmol} / \mathrm{l})$ & $16.89 \pm 3.77$ & $16.70 \pm 4.69$ & 0.170 & 0.866 & $10.47 \pm 3.80^{\mathrm{a}}$ & $10.56 \pm 2.59^{\mathrm{a}}$ & 0.103 & 0.918 \\
\hline $\mathrm{HbA1c}(\%)$ & $8.56 \pm 1.25$ & $8.86 \pm 3.17$ & 0.471 & 0.640 & $6.97 \pm 1.25^{\mathrm{a}}$ & $7.35 \pm 2.48^{\mathrm{a}}$ & 0.749 & 0.457 \\
\hline
\end{tabular}

FBG, fasting blood glucose; $2 \mathrm{hPG}, 2$-hour postprandial blood glucose; HbA1c, hemoglobin A1c. ${ }^{\mathrm{a}} \mathrm{P}<0.05$ vs. before treatment.

CRP, TNF- $\alpha$, and IL-6 levels before and after treatment in the two groups. There were no intergroup differences in CRP, TNF- $\alpha$, and IL- 6 before treatment (all P>0.05). However, at six months after treatment, the levels of these markers improved greatly in the study group (all $\mathrm{P}<0.05$ ). The control group had improved levels of TNF- $\alpha$ and IL- 6 after treatment (both $\mathrm{P}<0.05)$. Intergroup differences were observed in the three markers after treatment, and the reductions in the study group were greater (all $\mathrm{P}<0.05$ ) (Table $\mathrm{V}$ and Fig. 3).

\section{Discussion}

Some clinical studies have displayed that elderly patients with T2DM are more likely to have CI, and the occurrence is often unnoticeable. The condition may be mild cognitive dysfunction in the beginning but turns to dementia as it progresses.

Pathogenesis of the disease may be associated with various factors, including $\mathrm{A} \beta$ gathering, chronic inflammation, and age, making CI more easily developed in elderly patients with 
Table III. Score of cognitive ability before and after treatment in the two groups.

\begin{tabular}{|c|c|c|c|c|c|c|c|c|}
\hline Scores & $\begin{array}{l}\text { Study group } \\
\text { Before } \\
\text { treatment }\end{array}$ & $\begin{array}{c}\text { Control group } \\
\text { Before } \\
\text { treatment }\end{array}$ & t value & P-value & $\begin{array}{l}\text { Study group } \\
\text { After } \\
\text { treatment }\end{array}$ & $\begin{array}{c}\text { Control group } \\
\text { After } \\
\text { treatment }\end{array}$ & t value & P-value \\
\hline MMSE & $25.42 \pm 1.22$ & $25.37 \pm 1.16$ & 0.108 & 0.914 & $26.83 \pm 0.91^{\mathrm{a}}$ & $22.70 \pm 1.80^{\mathrm{a}}$ & 11.201 & $<0.001$ \\
\hline MoCA & $22.50 \pm 1.94$ & $22.20 \pm 2.35$ & 0.538 & 0.592 & $23.73 \pm 2.03^{\mathrm{a}}$ & $22.23 \pm 2.18$ & 2.759 & 0.008 \\
\hline
\end{tabular}

MMSE, Mini-Mental State Examination; MoCA, Montreal Cognitive Assessment. ${ }^{a} \mathrm{P}<0.05$ vs. before treatment within the same group.

Table IV. A $\beta 1-42, A \beta 1-40$, and $A \beta 1-42 / A \beta 1-40$ levels in plasma before and after treatment in the two groups.

\begin{tabular}{|c|c|c|c|c|c|c|c|c|}
\hline Markers & $\begin{array}{l}\text { Study group } \\
\text { Before } \\
\text { treatment }\end{array}$ & $\begin{array}{c}\text { Control group } \\
\text { Before } \\
\text { treatment }\end{array}$ & t value & P-value & $\begin{array}{l}\text { Study group } \\
\text { After } \\
\text { treatment }\end{array}$ & $\begin{array}{c}\text { Control group } \\
\text { After } \\
\text { treatment }\end{array}$ & t value & P-value \\
\hline $\mathrm{A} \beta 1-42$ (ng/l) & $18.37 \pm 5.08$ & $17.73 \pm 4.64$ & 0.504 & 0.616 & $19.03 \pm 3.17$ & $19.40 \pm 5.05$ & 0.337 & 0.737 \\
\hline $\mathrm{A} \beta 1-40(\mathrm{ng} / \mathrm{l})$ & $46.50 \pm 11.19$ & $43.80 \pm 9.98$ & 0.987 & 0.328 & $41.03 \pm 9.18$ & $44.97 \pm 10.83$ & 1.517 & 0.135 \\
\hline $\mathrm{A} \beta 1-42 / \mathrm{A} \beta 1-40$ & $0.39 \pm 0.04$ & $0.40 \pm 0.02$ & 1.445 & 0.154 & $0.47 \pm 0.03^{\mathrm{a}}$ & $0.43 \pm 0.04$ & 4.649 & $<0.001$ \\
\hline
\end{tabular}

${ }^{\text {ap }}<0.05$ vs. before treatment within the same group.

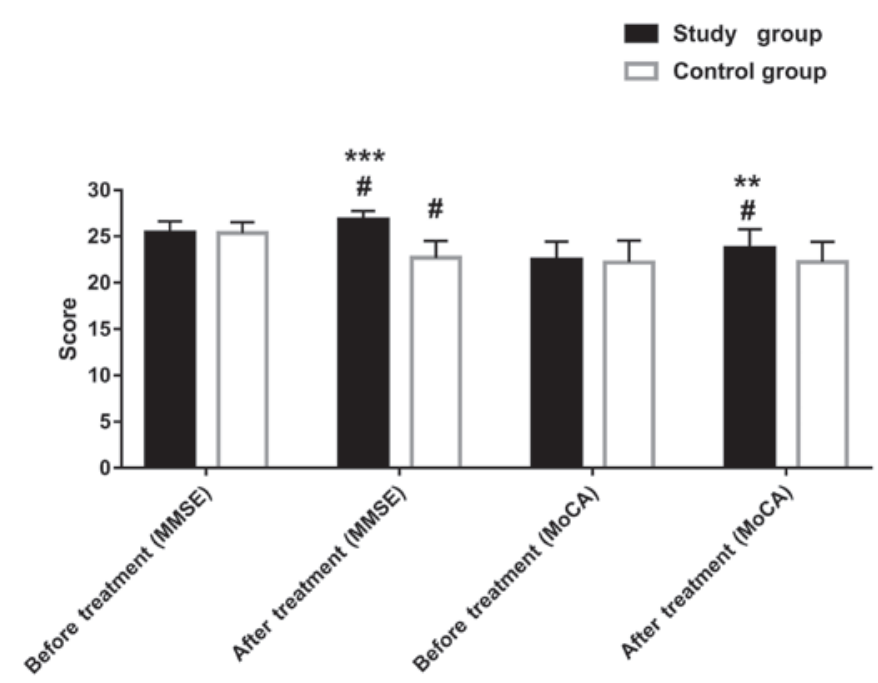

Figure 1. Score of cognitive ability before and after treatment in the two groups. MMSE, Mini-Mental State Examination; MoCA, Montreal Cognitive Assessment. ${ }^{* *} \mathrm{P}<0.01,{ }^{* * *} \mathrm{P}<0.001$ vs. the control group; ${ }^{\#} \mathrm{P}<0.05$ vs. before treatment.

T2DM; moreover, the occurrence of CI is closely correlated with glucose variability (19). Some researchers have reported that $\mathrm{CI}$ is more likely to occur in T2DM patients with longterm insulin resistance and hyperinsulinemia, and T2DM is regarded as a risk factor of CI. Furthermore, patients with T2DM and CI often have brain insulin resistance (20). Studies on stroke have indicated that in patients who had a stroke, the injury to neurovascular unit due to cerebra hypoxia-ischemia can impair cognitive ability $(21,22)$. Other studies have exhibited that DPP-4 inhibitor not only has better blood sugar lowering effect versus other hypoglycemic agents but also attenuates $\mathrm{CI}$ induced by $\mathrm{AD}(23-26)$. In the present study,

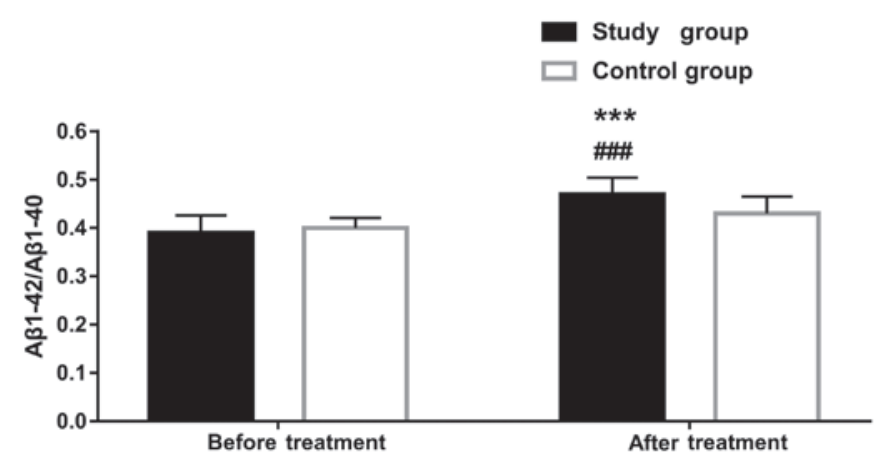

Figure 2. A $\beta 1-42 / A \beta 1-40$ level in plasma before and after treatment in the two groups. ${ }^{* * *} \mathrm{P}<0.001$ vs. the control group; ${ }^{\# \#} \mathrm{P}<0.001$ vs. before treatment.

we compared the efficacy of DPP-4 inhibitor sitagliptin with that of sulfonylurea in the treatment and observed that the two agents performed similarly in lowering blood sugar content. However, in terms of improving cognitive ability, the study group given DPP-4 inhibitor exhibited better MMSE and MoCA scores than the control group, which aligns with the studies above.

It has been demonstrated that $\mathrm{A} \beta$ gathering, decreased ability in regulating protein phosphorylation, and the participation of chronic inflammatory factors are common lesion characteristics in both T2DM and CI (27). Regarding the mechanism of improving cognitive ability, we studied the $A \beta$ gathering and chronic inflammatory factors. Some researchers have reported increased $A \beta$ expressions in cerebral cortex and hippocampus of mice with diabetes, whereas using DPP-4 inhibitor decreases A $\beta$ expression levels in these two areas (27). Another study has documented a reduction in $\mathrm{A} \beta$ expression in the cerebrospinal fluid of AD patients (28). 
Table V. CRP, TNF- $\alpha$, and IL-6 levels before and after treatment in the two groups.

\begin{tabular}{|c|c|c|c|c|c|c|c|c|}
\hline Factors & $\begin{array}{l}\text { Study group } \\
\text { Before } \\
\text { treatment }\end{array}$ & $\begin{array}{c}\text { Control group } \\
\text { Before } \\
\text { treatment }\end{array}$ & $\mathrm{t}$ value & P-value & $\begin{array}{l}\text { Study group } \\
\text { After } \\
\text { treatment }\end{array}$ & $\begin{array}{c}\text { Control group } \\
\text { After } \\
\text { treatment }\end{array}$ & $\mathrm{t}$ value & P-value \\
\hline CRP (mg/l) & $6.64 \pm 1.81$ & $6.90 \pm 1.84$ & 0.917 & 0.363 & $4.80 \pm 1.52^{\mathrm{a}}$ & $7.57 \pm 1.48$ & 7.153 & $<0.001$ \\
\hline TNF- $\alpha(\mu \mathrm{g} / \mathrm{ml})$ & $124.51 \pm 18.22$ & $123.80 \pm 17.87$ & 0.154 & 0.878 & $85.01 \pm 15.90^{\mathrm{a}}$ & $102.66 \pm 16.12^{\mathrm{a}}$ & 4.269 & $<0.001$ \\
\hline IL-6 $(\mu \mathrm{g} / \mathrm{ml})$ & $351.37 \pm 37.86$ & $351.00 \pm 37.32$ & 0.038 & 0.969 & $273.27 \pm 25.64^{\mathrm{a}}$ & $318.34 \pm 29.73^{\mathrm{a}}$ & 6.287 & $<0.001$ \\
\hline
\end{tabular}

CRP, C-reactive protein; TNF- $\alpha$, tumor necrosis factor- $\alpha$; IL- 6 - interleukin- 6 . ${ }^{a} \mathrm{P}<0.05$ vs. before treatment within the same group.

A
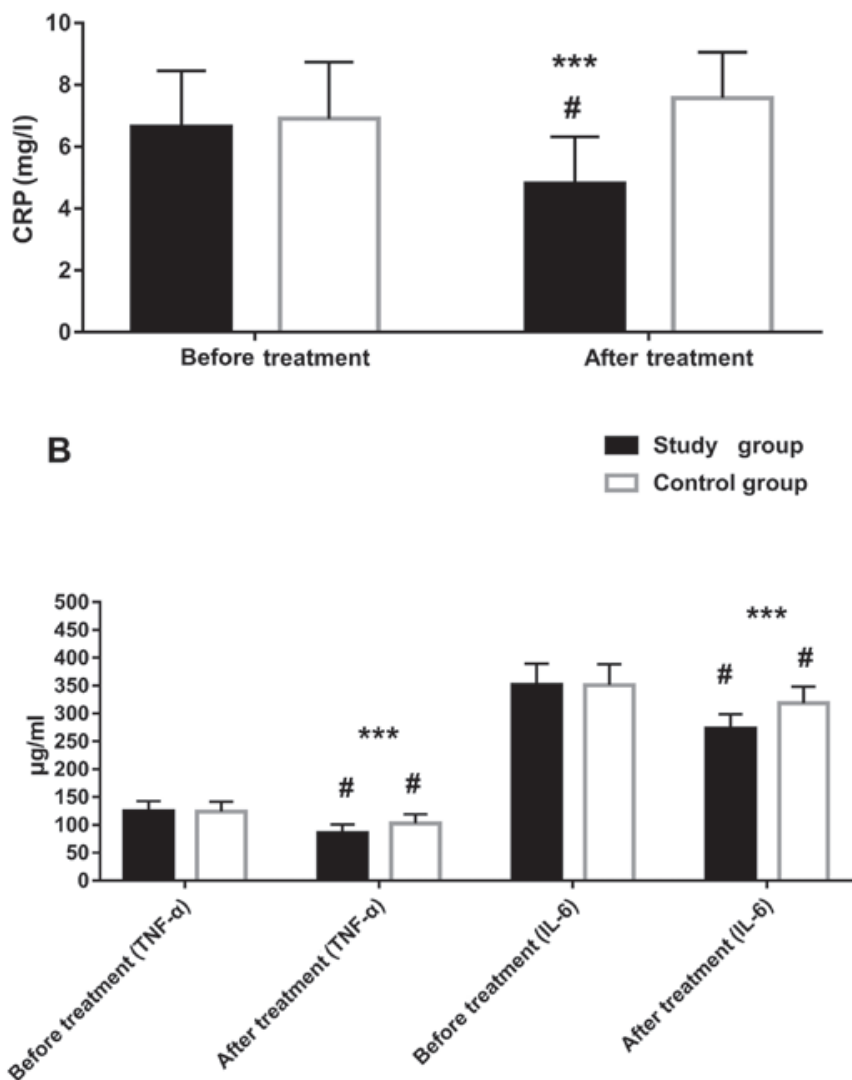

Figure 3. CRP, TNF- $\alpha$, and IL-6 levels before and after treatment in the two groups. (A) CRP level before and after treatment, (B) TNF- $\alpha$ and IL- 6 levels before and after treatment. CRP, C-reactive protein; TNF- $\alpha$, tumor necrosis factor- $\alpha$; IL-6, interleukin- 6 . ${ }^{* * * *} \mathrm{P}<0.001$ vs. the control group; ${ }^{\#} \mathrm{P}<0.05$ vs. before treatment.

However, it is not easy to perform a cerebrospinal fluid test during an early diagnosis of CI. Therefore, clinical studies were performed to find more easy-to-measure biomarkers in blood. Some studies on A $\beta 1-40$ and A $\beta 1-42$ have observed different expression changes including rising, no-change, and reduction in these two markers in plasma of patients with MCI (29-31). Moreover, the ratio of A $\beta 1-42$ to $A \beta 1-40$ has been found to decrease in patients with MCI, and the ratio reduces even much more in patients with $\mathrm{AD}$ (31). The high blood sugar content in T2DM can induce an immunoinflammatory response. It has been revealed that levels of CRP, TNF- $\alpha$, and IL- 6 can all elevate in T2DM patients (32). Inflammatory factors also exist in patients with CI. Some studies have reported elevated levels of various inflammatory factors in CI patients, leading to neuroinflammation. Due to inflammatory response, microglia and astrocyte can be excessively activated and produce toxic substances that damage neurons, thereby causing neuron denaturalization and apoptosis (33). IL-6 is a type of inflammatory factor. Previous studies reported that IL-6 expression could begin to increase in plasma during the early stage of AD (34). However, another study reported no difference in IL- 6 expression in serum between patients with MCI and normal people (35). CRP, a marker commonly used in clinic, is a protein synthesized in liver mediated by inflammatory factors such as IL-6 (36). In the present study, we compared the study group with the control group and found no intergroup differences in A $\beta 1-40$ and $A \beta 1-42$ in plasma before and after treatment in patients. After treatment, the study group had a significantly higher ratio of $A \beta 1-42$ to $A \beta 1-40$ than the control group. Moreover, no intergroup differences were observed in CRP, TNF- $\alpha$, and IL-6 levels before treatment, whereas these values were much lower in the study group than in the control group after treatment. These results align with previous findings.

There were still some limitations in the study. The sample size was small, requiring a study with a larger sample size in the future. Also, the study period was relatively short, and the study was affected by several external factors including area of infarction or bleeding, the difference in the treatment plan for infarction and bleeding, and recovery duration. Therefore, a longer follow-up will be needed in future studies.

In conclusion, using DPP-4 inhibitor in treating elderly patients with T2DM combined with post-stroke MCI can decrease blood sugar level and improve cognitive ability. The mechanism may be associated with the improvement of $A \beta$ gathering and reduction in the inflammatory response in the body.

\section{Acknowledgements}

Not applicable.

\section{Funding}

No funding was received. 


\section{Availability of data and materials}

The datasets used and/or analyzed during the current study are available from the corresponding author on reasonable request.

\section{Authors' contributions}

JX recorded and compared sugar blood content and wrote the manuscript. CW and CP conceived and designed the study. $\mathrm{CP}$ and $\mathrm{HX}$ were responsible for the collection and analysis of the experimental data. LX and XC interpreted the data and drafted the manuscript. XW and NW were responsible for the comparison of CRP, TNF- $\alpha$ and IL-6, and revised the manuscript critically for important intellectual content. All authors read and approved the final manuscript.

\section{Ethics approval and consent to participate}

The study was approved by the Ethics Committee of Heilongjiang Provincial Hospital (Harbin, China). Patients who participated in this research had complete clinical data. Signed written informed consents were obtained from the patients and/or guardians.

\section{Patient consent for publication}

Not applicable.

\section{Conflict of interest}

The authors declare that they have no competing interests.

\section{References}

1. Zaccardi F, Webb DR, Yates T and Davies MJ: Pathophysiology of type 1 and type 2 diabetes mellitus: A 90-year perspective. Postgrad Med J 92: 63-69, 2016.

2. Weuve J, Hebert LE, Scherr PA and Evans DA: Prevalence of Alzheimer disease in US states. Epidemiology 26: e4-e6, 2015.

3. Cumming TB, Marshall RS and Lazar RM: Stroke, cognitive deficits, and rehabilitation: still an incomplete picture. Int J Stroke 8: 38-45, 2013

4. Kosaraju J, Gali CC, Khatwal RB, Dubala A, Chinni S, Holsinger RM, Madhunapantula VS, Muthureddy Nataraj SK and Basavan D: Saxagliptin: A dipeptidyl peptidase-4 inhibitor ameliorates streptozotocin induced Alzheimer's disease. Neuropharmacology 72: 291-300, 2013.

5. Le Couteur DG, Wahl D and Naismith SL: Comorbidity and vascular cognitive impairment-no dementia (VCI-ND). Age Ageing 46: 705-707, 2017.

6. Shi D, Chen X and Li Z: Diagnostic test accuracy of the Montreal Cognitive Assessment in the detection of post-stroke cognitive impairment under different stages and cutoffs: a systematic review and meta-analysis. Neurol Sci 39: 705-716, 2018.

7. Kosaraju J, Murthy V, Khatwal RB, Dubala A, Chinni S, Muthureddy Nataraj SK and Basavan D: Vildagliptin: An antidiabetes agent ameliorates cognitive deficits and pathology observed in streptozotocin-induced Alzheimer's disease. J Pharm Pharmacol 65: 1773-1784, 2013.

8. Kornelius E, Lin CL, Chang HH, Li HH, Huang WN, Yang YS, Lu YL, Peng $\mathrm{CH}$ and Huang CN: DPP-4 Inhibitor linagliptin attenuates $\mathrm{A} \beta$-induced cytotoxicity through activation of AMPK in neuronal cells. CNS Neurosci Ther 21: 549-557, 2015.

9. Graaf C, Donnelly D, Wootten D, Lau J, Sexton PM, Miller LJ Ahn JM, Liao J, Fletcher MM, Yang D, et al: Glucagon-like peptide-1 and its class B G protein-coupled receptors: A long march to therapeutic successes. Pharmacol Rev 68: 954-1013, 2016.
10. Tramutola A, Arena A, Cini C, Butterfield DA and Barone E: Modulation of GLP-1 signaling as a novel therapeutic approach in the treatment of Alzheimer's disease pathology. Expert Rev Neurother 17: 59-75, 2017

11. Hansen HH, Barkholt P, Fabricius K, Jelsing J, Terwel D, Pyke C, Knudsen LB and Vrang N: The GLP-1 receptor agonist liraglutide reduces pathology-specific tau phosphorylation and improves motor function in a transgenic hTauP301L mouse model of tauopathy. Brain Res 1634: 158-170, 2016.

12. Candeias EM, Sebastião IC, Cardoso SM, Correia SC, Carvalho CI, Plácido AI, Santos MS, Oliveira CR, Moreira PI and Duarte AI: Gut-brain connection: The neuroprotective effects of the antidiabetic drug liraglutide. World J Diabetes 6: 807-827, 2015.

13. Wang X, Wang L, Jiang R, Xu Y, Zhao X and Li Y: Exendin-4 antagonizes $A \beta 1-42$-induced attenuation of spatial learning and memory ability. Exp Ther Med 12: 2885-2892, 2016.

14. Isik AT, Soysal P, Yay A and Usarel C: The effects of sitagliptin, a DPP-4 inhibitor, on cognitive functions in elderly diabetic patients with or without Alzheimer's disease. Diabetes Res Clin Pract 123: 192-198, 2017.

15. Yin Y, Gao D, Wang Y, Wang ZH, Wang X, Ye J, Wu D, Fang L, Pi G, Yang Y, et al: Tau accumulation induces synaptic impairment and memory deficit by calcineurin-mediated inactivation of nuclear CaMKIV/CREB signaling. Proc Natl Acad Sci USA 113: E3773-E3781, 2016.

16. Ogedengbe S, Ezeani IU and Aihanuwa E: Comparison of clinical and biochemical variables in type 2 diabetes mellitus patients and their first-degree relatives with metabolic syndrome in Benin City, Nigeria: A cross sectional case controlled study. Endocr Regul 50: 32-40, 2016.

17. Blum S, Luchsinger JA, Manly JJ, Schupf N, Stern Y, Brown TR, DeCarli C, Small SA, Mayeux R and Brickman AM: Memory after silent stroke: hippocampus and infarcts both matter. Neurology 78: 38-46, 2012.

18. Ciesielska N, Sokołowski R, Mazur E, Podhorecka M, PolakSzabela A and Kędziora-Kornatowska K: Is the Montreal Cognitive Assessment (MoCA) test better suited than the Mini-Mental State Examination (MMSE) in mild cognitive impairment (MCI) detection among people aged over 60? Metaanalysis. Psychiatr Pol 50: 1039-1052, 2016 (In Polish).

19. Rizzo MR, Marfella R, Barbieri M, Boccardi V, Vestini F, Lettieri B, Canonico S and Paolisso G: Relationships between daily acute glucose fluctuations and cognitive performance among aged type 2 diabetic patients. Diabetes Care 33: 2169-2174, 2010.

20. Watson GS and Craft S: Modulation of memory by insulin and glucose: Neuropsychological observations in Alzheimer's disease. Eur J Pharmacol 490: 97-113, 2004.

21. Zheng G, Zheng Y, Xiong Z, Ye B, Tao J and Chen L: Effect of Baduanjin exercise on cognitive function in patients with poststroke cognitive impairment: Study protocol for a randomised controlled trial. BMJ Open 8: e020954, 2018.

22. Rosenberg GA: Extracellular matrix inflammation in vascular cognitive impairment and dementia. Clin Sci (Lond) 131: 425-437, 2017.

23. Zhou JB, Bai L, Wang Y and Yang JK: The benefits and risks of DPP4-inhibitors vs. sulfonylureas for patients with type 2 diabetes: Accumulated evidence from randomised controlled trial. Int J Clin Pract 70: 132-141, 2016.

24. Loh HH, Yee A, Loh HS, Sukor N and Kamaruddin NA: Comparative studies of dipeptidyl peptidase 4 inhibitor vs sulphonylurea among Muslim Type 2 diabetes patients who fast in the month of Ramadan: A systematic review and meta-analysis. Prim Care Diabetes 10: 210-219, 2016.

25. Bekiari E, Rizava C, Athanasiadou E, Papatheodorou K, Liakos A, Karagiannis T, Mainou M, Rika M, Boura P and Tsapas A: Systematic review and meta-analysis of vildagliptin for treatment of type 2 diabetes. Endocrine 52: 458-480, 2016.

26. Xi YD, Zhang DD, Ding J, Yu HL, Yuan LH, Ma WW, Han J and Xiao R: Genistein inhibits A $\beta 25-35$-induced synaptic toxicity and regulates CaMKII/CREB pathway in SH-SY5Y cells. Cell Mol Neurobiol 36: 1151-1159, 2016.

27. Kosaraju J, Holsinger RMD, Guo L and Tam KY: Linagliptin, a dipeptidyl peptidase-4 inhibitor, mitigates cognitive deficits and pathology in the 3xTg-AD mouse model of Alzheimer's disease. Mol Neurobiol 54: 6074-6084, 2017.

28. de Leon MJ, Pirraglia E, Osorio RS, Glodzik L, Saint-Louis L, Kim HJ, Fortea J, Fossati S, Laska E, Siegel C, et al; Alzheimer's Disease Neuroimaging Initiative; National Alzheimer's Coordinating Center: The nonlinear relationship between cerebrospinal fluid A $\beta 42$ and tau in preclinical Alzheimer's disease. PLoS One 13: e0191240, 2018. 
29. Mayeux R, Honig LS, Tang MX, Manly J, Stern Y, Schupf N and Mehta PD: Plasma A[beta]40 and A[beta]42 and Alzheimer's disease: Relation to age, mortality, and risk. Neurology 61: $1185-1190,2003$

30. Rembach A, Faux NG, Watt AD, Pertile KK, Rumble RL, Trounson BO, Fowler CJ, Roberts BR, Perez KA, Li QX, et al; AIBL research group: Changes in plasma amyloid beta in a longitudinal study of aging and Alzheimer's disease. Alzheimers Dement 10: 53-61, 2014.

31. Janelidze S, Stomrud E, Palmqvist S, Zetterberg H, van Westen D, Jeromin A, Song L, Hanlon D, Tan Hehir CA, Baker D, et al: Plasma $\beta$-amyloid in Alzheimer's disease and vascular disease. Sci Rep 6: 26801, 2016

32. Ebtehaj S, Gruppen EG,Parvizi M, Tietge UJF and Dullaart RPF: The anti-inflammatory function of HDL is impaired in type 2 diabetes: Role of hyperglycemia, paraoxonase-1 and low grade inflammation. Cardiovasc Diabetol 16: 132, 2017.

33. Prati F,Bartolini M,Simoni E, De Simone A, Pinto A, Andrisano V and Bolognesi ML: Quinones bearing non-steroidal anti-inflammatory fragments as multitarget ligands for Alzheimer's disease. Bioorg Med Chem Lett 23: 6254-6258, 2013.
34. Mun MJ, Kim JH, Choi JY and Jang WC: Genetic polymorphisms of interleukin genes and the risk of Alzheimer's disease: An update meta-analysis. Meta Gene 8: 1-10, 2016.

35. Kim YS, Lee KJ and Kim H: Serum tumour necrosis factor- $\alpha$ and interleukin-6 levels in Alzheimer's disease and mild cognitive impairment. Psychogeriatrics 17: 224-230, 2017.

36. Zhang Q, Qian G and Ding Z: Xuemaitong granules attenuate carotid atherosclerosis by decreasing the expression of $\mathrm{CD} 14^{+} \mathrm{CD} 16^{+}$monocytes, IL- 6 , TNF- $\alpha$, and hsCRP. Genet Mol Res 13: 7519-7527, 2014.

(i) (5) This work is licensed under a Creative Commons Attribution-NonCommercial-NoDerivatives 4.0 International (CC BY-NC-ND 4.0) License. 